\title{
Aeromonas bivalvium sp. nov., isolated from bivalve molluscs
}

\author{
David Miñana-Galbis, Maribel Farfán, M. Carme Fusté and J. Gaspar Lorén
}

Correspondence

J. Gaspar Lorén

jgloren@ub.edu

\author{
Departament de Microbiologia i Parasitologia Sanitàries, Facultat de Farmàcia, Universitat de \\ Barcelona, Av. Joan XXIII s/n, 08028 Barcelona, Spain
}

\begin{abstract}
A polyphasic study was performed to determine the taxonomic position of two Aeromonas strains, $665 \mathrm{~N}$ and $868 \mathrm{E}^{\top}$, isolated from bivalve molluscs, that could not be identified at the species level in a previous numerical taxonomy study. The DNA $\mathrm{G}+\mathrm{C}$ content of these isolates was 62.3 and $62.6 \mathrm{~mol} \%$, respectively. Sequence analysis of the 16S rRNA gene showed that the two new strains were closely related to members of the genus Aeromonas. Fluorescence amplified fragment length polymorphism fingerprinting revealed that strains $665 \mathrm{~N}$ and $868 \mathrm{E}^{\top}$ clustered together with a similarity of $78 \%$ but did not cluster with any of the Aeromonas genomospecies. DNA-DNA hybridization experiments revealed a high level of relatedness between the two new isolates (76\%) but low levels of relatedness between these and phylogenetically most closely related Aeromonas genomospecies (30-44\%). Useful tests for the phenotypic differentiation of strains $665 \mathrm{~N}$ and $868 \mathrm{E}^{\top}$ from other mesophilic Aeromonas species included those for gas from glucose, lysine decarboxylase, Voges-Proskauer reaction, acid from L-arabinose, hydrolysis of aesculin and utilization of L-lactate. On the basis of genotypic and phenotypic evidence, strains $665 \mathrm{~N}$ and $868 \mathrm{E}^{\top}$ are considered to represent a novel species of the genus Aeromonas, for which the name Aeromonas bivalvium sp. nov. is proposed. The type strain is $868 \mathrm{E}^{\top}\left(=\mathrm{CECT} 7113^{\top}=\mathrm{LMG}\right.$ $\left.23376^{\top}\right)$.
\end{abstract}

Members of the genus Aeromonas, belonging to the class Gammaproteobacteria, are Gram-negative, non-spore-forming bacilli or coccobacilli, and are facultatively anaerobic, chemo-organotrophic, oxidase- and catalase-positive, resistant to the vibriostatic agent O/129 (2,4-diamino-6,7diisopropylpteridine), generally motile by means of a single polar flagellum and are able to reduce nitrate to nitrite. Aeromonads are primarily aquatic, widespread in environmental habitats, frequently isolated from foods and often associated with aquatic animals, and some species are primary or opportunistic pathogens in invertebrates and vertebrates including humans (Martin-Carnahan \& Joseph, 2005).

At the time of writing, 17 Aeromonas species and 20 DNADNA hybridization groups (HGs) have been described: Aeromonas hydrophila (HG1), A. bestiarum (HG2), A. salmonicida (HG3), A. caviae (HG4), A. media (HG5), A.

Abbreviations: FAFLP, fluorescence amplified fragment length polymorphism; $H G$, hybridization group.

The GenBank/EMBL/DDBJ accession numbers for the $16 \mathrm{~S}$ rRNA gene sequences of strains $868 \mathrm{E}^{\top}$ and $665 \mathrm{~N}$ are D0504429 and D0504430, respectively.

A table giving levels of DNA-DNA hybridization between strains $868 \mathrm{E}^{\top}$ and $665 \mathrm{~N}$ and strains of phylogenetically related Aeromonas species is available as supplementary material in IJSEM Online. eucrenophila (HG6), A. sobria (HG7), A. veronii bv. Sobria (HG8/10), A. jandaei (HG9), A. veronii bv. Veronii (HG10/ 8), Aeromonas sp. HG11, A. schubertii (HG12), Aeromonas sp. group 501 (HG13), A. trota (HG14), A. allosaccharophila (HG15), A. encheleia (HG16), A. popoffii (HG17), A. culicicola (HG18), A. simiae (HG19) and A. molluscorum (HG20) (Pidiyar et al., 2002; Harf-Monteil et al., 2004; Miñana-Galbis et al., 2004; Martin-Carnahan \& Joseph, 2005). In addition to the continuous description of novel species, the complexity of Aeromonas taxonomy results from the isolation of motile and non-motile, mesophilic and psychrophilic, pigmented and non-pigmented strains within several Aeromonas species (Altwegg et al., 1990; Martin-Carnahan \& Joseph, 2005), description of novel subspecies of $A$. hydrophila (Huys et al., 2002, 2003) and $A$. salmonicida (Pavan et al., 2000), taxonomic rearrangement of Aeromonas sp. HG11 (Huys et al., 1997) and A. culicicola (Huys et al., 2005) and extended descriptions of $A$. eucrenophila and A. encheleia (Huys et al., 1997) and $A$. jandaei (Esteve et al., 2003). In this context, several authors have proposed useful tables for the phenotypic differentiation of Aeromonas species based on a limited number of key tests (Carson et al., 2001; Miñana-Galbis et al., 2002, 2004; Valera \& Esteve, 2002; Abbott et al., 2003; Martin-Carnahan \& Joseph, 2005). Genotypic classification of aeromonads at the genus level is currently recommended based on DNA $\mathrm{G}+\mathrm{C}$ content and for species delineation based on $16 \mathrm{~S}$ 
rRNA gene sequence analyses and DNA-DNA reassociation experiments, although other genomic methods, such as DNA profiling or $r p o D$ and $g y r B$ gene sequencing, are useful for Aeromonas species discrimination (Stackebrandt et al., 2002; Soler et al., 2004; Martin-Carnahan \& Joseph, 2005; Morandi et al., 2005).

In the present study, a polyphasic approach was used in order to determine the taxonomic position of two Aeromonas strains isolated from bivalve molluscs that clustered together as a separate phenon (phenon VII) but could not be identified at the species level in a previous phenotypic study of the genus Aeromonas (Miñana-Galbis et al., 2002). For this purpose, an extended phenotypic characterization, 16S rRNA gene sequencing, DNA G $+\mathrm{C}$ content determination, fluorescence amplified fragment length polymorphism (FAFLP) analysis and DNA-DNA hybridization experiments were performed for the two isolates. Based on the results obtained, these strains are considered to represent a novel species of the genus Aeromonas.

Strains $868 \mathrm{E}^{\mathrm{T}}$ and $665 \mathrm{~N}$ were isolated from cockles (Cardium sp.) and razor shells (Ensis sp.), respectively, from retail markets in Barcelona (Spain). Isolation, growth and preservation of strains were performed as described previously (Miñana-Galbis et al., 2004).

Cell size, morphology and flagellar arrangement were determined by transmission electron microscopy (JEOL 1010). Cells were grown on trypticase soy agar (TSA) supplemented with $0.5 \%(\mathrm{w} / \mathrm{v}) \mathrm{NaCl}$ for $24 \mathrm{~h}$ at $25^{\circ} \mathrm{C}$ and, following further suspension in MilliQ water, were examined by negative staining with $2 \%(\mathrm{w} / \mathrm{v})$ uranyl acetate.

Physiological and biochemical characterization experiments, unless stated otherwise, were performed at 25$30{ }^{\circ} \mathrm{C}$ and all media contained $1 \%(\mathrm{w} / \mathrm{v}) \mathrm{NaCl}$. Tests for the following were determined as described previously (Miñana-Galbis et al., 2002): Gram-staining, motility, glucose oxidation-fermentation, oxidase and catalase activity, nitrate reduction, indole production, susceptibility to $\mathrm{O} /$ 129 , swarming motility, production of a brown diffusible pigment, gas production from D-glucose, methyl red and Voges-Proskauer reactions, ONPG, hydrogen sulfide production from cysteine and thiosulfate, growth on MacConkey agar and m-Aeromonas-selective agar base Havelaar, salt tolerance, $\mathrm{pH}$ and temperature ranges for growth, acid production from carbohydrates, hydrolysis of aesculin, arbutin, DNA, elastin, erythrocytes, starch, urea and xanthine, utilization of substrates as sole carbon and energy sources and sensitivity to antibiotics. Arginine dihydrolase, lysine decarboxylase and ornithine decarboxylase activity (Moeller's method) and hydrolysis of gelatin by using tannic acid $(1 \%)$ as the gelatin-precipitating reagent were determined as described by Smibert \& Krieg (1994).

For 16S rRNA gene sequencing and phylogenetic analysis, DNA was extracted by using a REALPURE genomic DNA extraction kit (RBMEG03; Durviz). Oligonucleotide primers used for PCR amplification and sequencing of the $16 \mathrm{~S}$ rRNA gene were those described by Martínez-Murcia et al. (1999). DNA was subjected to PCR amplification in a total volume of $50 \mu \mathrm{l}$ that contained $50 \mathrm{mM} \mathrm{KCl}, 15 \mathrm{mM}$ Tris/ $\mathrm{HCl}$ (pH 8.0), $1.5 \mathrm{mM} \mathrm{MgCl}_{2}, 0.2 \mathrm{mM}$ each dNTP (Amersham Biosciences), $1.25 \mathrm{U}$ AmpliTaq Gold DNA polymerase (Applera) and $25 \mathrm{pmol}$ each primer. The reaction mixtures were subjected to the following thermal cycling: an initial single step of $95^{\circ} \mathrm{C}$ for $9 \mathrm{~min}, 35$ cycles of $94{ }^{\circ} \mathrm{C}$ for $60 \mathrm{~s}, 51{ }^{\circ} \mathrm{C}$ for $30 \mathrm{~s}$ and $72{ }^{\circ} \mathrm{C}$ for $90 \mathrm{~s}$ and a final single step of $72{ }^{\circ} \mathrm{C}$ for $10 \mathrm{~min}$. PCR products were purified by using Montage PCR centrifugal filter devices (Millipore) and prepared for sequencing by employing a BigDye Terminator v3.1 cycle sequencing kit (Applera). The amplified 16S rRNA genes were sequenced with an ABI PRISM 3730 DNA analyser by the Unitat de Genòmica of the Serveis Cientificotècnics of the Universitat de Barcelona.

The sequences obtained were aligned with 16S rRNA gene sequences of the type or reference strains of the Aeromonas DNA HGs by using the DNASTAR Lasergene software. Distances and clustering with the neighbour-joining and maximum-parsimony methods (pairwise deletion and Kimura two-parameter model) were determined by using MEGA version 2.1 (Kumar et al., 2001). Stability of the relationships was assessed by bootstrapping (1000 replicates).

DNA fingerprinting using FAFLP, which included DNA extraction and purification (Gevers et al., 2001), FAFLP fingerprinting, data processing and numerical analysis (Huys \& Swings, 1999), was performed by the $\mathrm{BCCM}^{\mathrm{TM}}$ / LMG (Belgian Coordinated Collections of Microorganisms/ Laboratorium voor Microbiologie from Universiteit Gent) Identification Service.

For DNA-DNA hybridization experiments and determination of DNA G + C content, genomic DNA of bacterial strains was prepared according to a modification of the procedure of Wilson (1987). The G $+\mathrm{C}$ content of each DNA sample was determined by three independent analyses via the HPLC technique (Mesbah et al., 1989). DNA-DNA hybridizations were performed in a minimum of four replicates at $47^{\circ} \mathrm{C}$ according to a modification of the method described by Ezaki et al. (1989). These analyses were also performed by the BCCM ${ }^{\mathrm{TM}} / \mathrm{LMG}$ Identification Service.

Strains $868 \mathrm{E}^{\mathrm{T}}$ and $665 \mathrm{~N}$ were identified as belonging to the genus Aeromonas as they were Gram-negative, rod-shaped, motile by means of one polar flagellum, oxidase-positive, facultatively anaerobic, glucose-fermentative and resistant to $\mathrm{O} / 129$ and they grew in the absence of $\mathrm{NaCl}$ but not at $7 \%$ $(\mathrm{w} / \mathrm{v}) \mathrm{NaCl}$. Cells of the two isolates was coccoid to rodshaped $(0.3-1.0 \times 0.5-2 \mu \mathrm{m})$. Their antibiotic-resistance pattern was similar to that of most recognized Aeromonas species (Kämpfer et al., 1999). The two strains were resistant to ampicillin and strain $665 \mathrm{~N}$ was also resistant to cephalothin, whereas strain $868 \mathrm{E}^{\mathrm{T}}$ was not. These strains 
formed non-pigmented, circular colonies with a diameter of $3-4 \mathrm{~mm}$ on TSA when incubated at $25-30^{\circ} \mathrm{C}$. The growth temperature range was $4-37^{\circ} \mathrm{C}$, although strain $868 \mathrm{E}^{\mathrm{T}}$ was able to grow at $40.5^{\circ} \mathrm{C}$. Optimal growth occurred at $30-37^{\circ} \mathrm{C}$. The two isolates showed several differential phenotypic features with regard to other mesophilic Aeromonas species (Table 1). Three or more tests allowed differentiation of strains $665 \mathrm{~N}$ and $868 \mathrm{E}^{\mathrm{T}}$ from all recognized Aeromonas species except A. caviae and A. media. A positive reaction in the lysine decarboxylase test allowed the separation of these strains from A. caviae and $A$. media. In addition, they could be differentiated from $A$. media based on the following tests: production of ONPG and brown pigment, fermentation of lactose and mannose and utilization of lactose, mannose and raffinose. In contrast to A. caviae, strains $665 \mathrm{~N}$ and $868 \mathrm{E}^{\mathrm{T}}$ were able to use glycerol and to produce acid from it. These results allowed the phenotypic discrimination of strains $665 \mathrm{~N}$ and $868 \mathrm{E}^{\mathrm{T}}$ from all recognized Aeromonas taxa.

Comparative analysis of $16 \mathrm{~S}$ rRNA gene sequences of strains $665 \mathrm{~N}$ and $868 \mathrm{E}^{\mathrm{T}}$ and those of all type or reference strains of Aeromonas species confirmed that the new isolates belonged to the genus Aeromonas. $16 \mathrm{~S}$ rRNA gene sequence similarity between strains $665 \mathrm{~N}$ and $868 \mathrm{E}^{\mathrm{T}}$ and other Aeromonas species ranged from $96.75 \%$ (to A. simiae) to $99.71 \%$ (to A.popoffii). Dendrograms generated by the maximum-parsimony and neighbour-joining methods were similar. The phylogenetic tree constructed by the neighbour-joining method is shown in Fig. 1. The sequences of strains $665 \mathrm{~N}$ and $868 \mathrm{E}^{\mathrm{T}}$ differed by $2 \mathrm{nt}$ from each other and by 4 and $6 \mathrm{nt}$ differences, respectively, with regard to that of $A$. popoffii (Table 2).

The FAFLP banding patterns of strains $665 \mathrm{~N}$ and $868 \mathrm{E}^{\mathrm{T}}$ were compared with the laboratory database AEROLIB, which comprises well-characterized strains of all Aeromonas DNA HGs (Huys \& Swings, 1999; Huys et al., 2003; MiñanaGalbis et al., 2004). This comparison revealed that isolates $665 \mathrm{~N}$ and $868 \mathrm{E}^{\mathrm{T}}$ clustered together with a similarity of $78 \%$ but did not cluster within any of the 20 Aeromonas DNA HGs currently described. A dendrogram of the cluster analysis of FAFLP fingerprints is shown in Fig. 2. These results indicated that strains $665 \mathrm{~N}$ and $868 \mathrm{E}^{\mathrm{T}}$ probably belonged to the same species and represented a novel Aeromonas species.

The DNA G + C content of strains $665 \mathrm{~N}$ and $868 \mathrm{E}^{\mathrm{T}}$ was 62.3 and $62.6 \mathrm{~mol} \%$, respectively, which agrees with the range described for the genus Aeromonas (57-63 mol\%; MartinCarnahan \& Joseph, 2005). Levels of DNA-DNA relatedness were determined between the type strain of the presumptively novel Aeromonas species $\left(868 \mathrm{E}^{\mathrm{T}}\right)$ and the type or reference strains of the phylogenetically most closely related Aeromonas HGs (Fig. 1) and between strains $868 \mathrm{E}^{\mathrm{T}}$ and

Table 1. Key tests for the phenotypic differentiation of strains $665 \mathrm{~N}$ and $868 \mathrm{E}^{\mathrm{T}}$ from other mesophilic Aeromonas species

Data were taken from Miñana-Galbis et al. (2004) and Martin-Carnahan \& Joseph (2005) unless indicated otherwise. Taxa: 1, strains 665N and $868 \mathrm{E}^{\mathrm{T}}$ (data from this study); 2, A. hydrophila; 3, A. bestiarum; 4, A. salmonicida; 5, A. caviae; 6, A. media; 7, A. eucrenophila; 8, A. sobria; 9, A. veronii bv. Sobria; 10, A. jandaei; 11, A. veronii bv. Veronii; 12, A. schubertii; 13, A. trota; 14, A. allosaccharophila; 15, A. encheleia; 16, A. popoffii 17, A. culicicola; 18, A. simiae; 19, A. molluscorum. +, 85-100\% of strains positive; d, 16-84\% of strains positive; $0-15 \%$ of strains positive; ND, no data available. Results obtained in this study for reference strains are given in parentheses.

\begin{tabular}{|c|c|c|c|c|c|c|c|c|c|c|c|c|c|c|c|c|c|c|c|}
\hline Characteristic & 1 & 2 & 3 & 4 & 5 & 6 & 7 & 8 & 9 & 10 & 11 & 12 & 13 & 14 & 15 & 16 & 17 & 18 & 19 \\
\hline \multicolumn{20}{|l|}{ Production of: } \\
\hline Brown pigment & - & - & - & - & - & + & - & - & - & - & - & - & - & - & - & - & - & - & - \\
\hline Gas from D-glucose & - & + & + & + & - & - & + & + & + & + & + & - & + & + & + & + & + & - & - \\
\hline $\mathrm{H}_{2} \mathrm{~S}$ from cysteine & - & + & + & + & - & - & + & + & + & + & $\mathrm{d}$ & - & + & + & + & $(+)$ & $(+)$ & $(-)$ & - \\
\hline Indole & + & + & + & + & + & + & + & + & + & + & + & - & + & + & + & $(+)$ & + & - & - \\
\hline Lysine decarboxylase & + & + & + & + & - & - & - & + & + & + & + & + & + & + & - & - & + & + & - \\
\hline Ornithine decarboxylase & - & - & - & - & - & - & - & - & - & - & + & - & - & $\mathrm{d}$ & - & - & - & - & - \\
\hline Voges-Proskauer reaction & - & + & + & + & - & - & - & + & + & + & + & + & - & - & - & + & + & - & - \\
\hline \multicolumn{20}{|l|}{ Acid from: } \\
\hline L-Arabinose & + & $\mathrm{d}$ & + & + & + & + & + & - & $\mathrm{d}$ & - & - & - & - & + & - & $\mathrm{d}$ & - & - & + \\
\hline D-Mannitol & + & + & + & + & + & + & + & + & + & + & + & - & + & + & + & + & + & - & + \\
\hline Sorbitol & - & - & - & + & - & - & - & - & - & - & - & - & - & - & - & - & - & - & - \\
\hline Sucrose & + & + & + & + & + & + & $\mathrm{d}$ & + & + & $\mathrm{d}$ & + & - & - & + & $\mathrm{d}$ & - & + & + & + \\
\hline \multicolumn{20}{|l|}{ Hydrolysis of: } \\
\hline Aesculin & + & + & + & + & + & + & + & - & - & - & + & - & - & + & + & $(-)$ & $(-)$ & $(-)$ & + \\
\hline Arbutin & + & + & + & + & + & + & + & - & - & - & + & - & $\mathrm{d}$ & - & + & $(-)$ & $(-)$ & $(+)$ & + \\
\hline Elastin & - & + & $\mathrm{d}$ & + & - & - & - & - & - & $\mathrm{d}$ & - & - & - & - & - & - & $(-)$ & $(-)$ & - \\
\hline Starch & + & + & + & + & + & + & + & + & - & + & + & + & - & - & + & + & + & $(+)$ & - \\
\hline Utilization of L-lactate & + & + & - & - & $\mathrm{d}$ & + & - & - & - & - & - & + & + & $\mathrm{d}$ & - & + & ND & $\mathrm{ND}$ & $\mathrm{d}$ \\
\hline
\end{tabular}




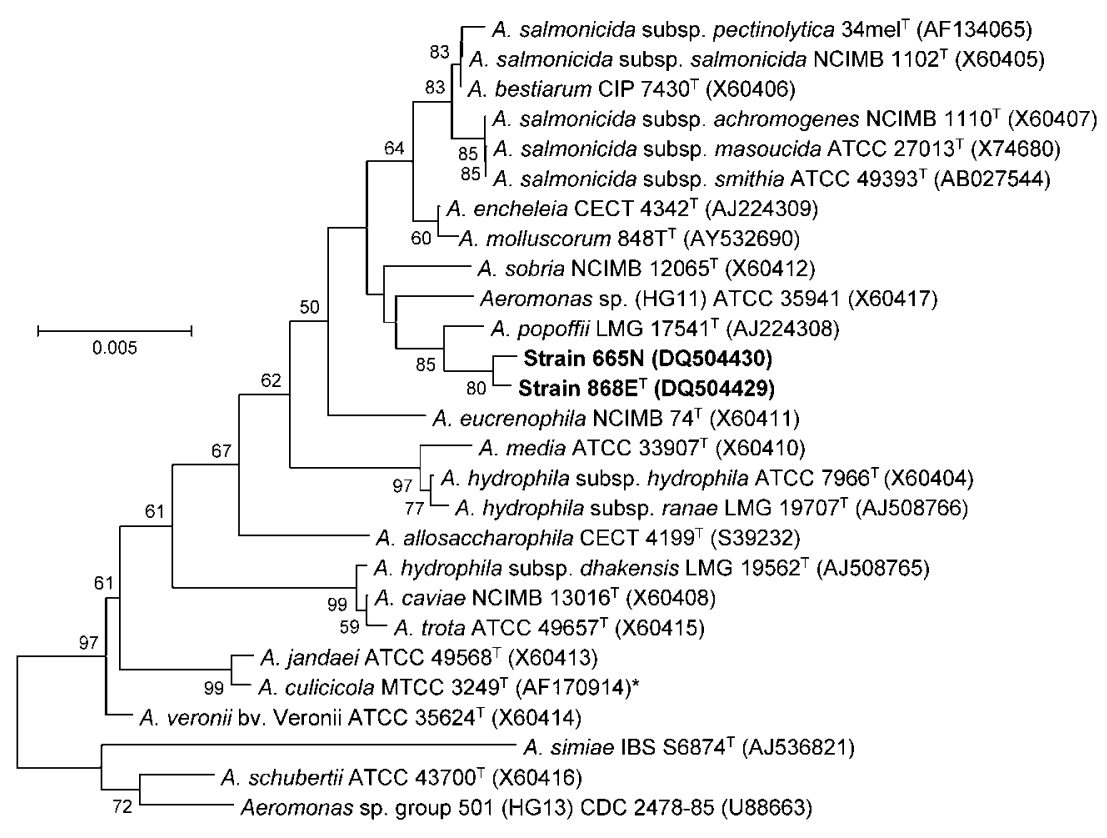

Fig. 1. Phylogenetic relationships of strains $665 \mathrm{~N}$ and $868 \mathrm{E}^{\top}$ to type or reference strains of the genus Aeromonas. The phylogenetic tree was constructed by using $1544 \mathrm{nt}$ of the 16S rRNA gene sequence by the neighbourjoining method in MEGA version 2.1. Bootstrap values $(>50 \%)$ based on 1000 replicates are shown. Bar, $0.5 \%$ sequence divergence. ${ }^{*} A$. culicicola is a later heterotypic synonym of $A$. veronii (Huys et al., 2005).
$665 \mathrm{~N}$. Strains $868 \mathrm{E}^{\mathrm{T}}$ and $665 \mathrm{~N}$ showed a level of DNA-DNA relatedness of $76 \%$, above the level of $70 \%$ that is accepted as the limit for species delineation (Wayne et al., 1987). Strain $868 \mathrm{E}^{\mathrm{T}}$ clearly showed $<70 \%$ DNA reassociation (30-44\%) with any of the type or reference Aeromonas strains analysed (see Supplementary Table S1 in IJSEM Online).

Based on the results of DNA-DNA hybridization, phenotypic characterization, FAFLP analysis and 16S rRNA gene sequencing, we consider that strains $868 \mathrm{E}^{\mathrm{T}}$ and $665 \mathrm{~N}$ represent a single novel species of the genus Aeromonas, for which the name Aeromonas bivalvium sp. nov. is proposed.

\section{Description of Aeromonas bivalvium sp. nov.}

Aeromonas bivalvium (bi.val'vi.um. N.L. pl. neut. n. Bivalvia scientific name of a class of molluscs; N.L. neut. gen. pl. n. bivalvium of bivalves of the class Bivalvia).

Cells are Gram-negative, straight, motile coccoids/rods with a polar flagellum, $0.5-2.0 \mu \mathrm{m}$ long and $0.3-1.0 \mu \mathrm{m}$ wide. Colonies on TSA are 3-4 $\mathrm{mm}$ in diameter, opaque, circular and beige in colour after $48 \mathrm{~h}$ at $25^{\circ} \mathrm{C}$. Optimal growth occurs at $30-37{ }^{\circ} \mathrm{C}$ but growth occurs at $4-37^{\circ} \mathrm{C}$ and strain $868 \mathrm{E}^{\mathrm{T}}$ grows at up to $40.5^{\circ} \mathrm{C}$. Oxidase- and catalase-positive, reduces nitrate to nitrite, produces indole from tryptophan and is resistant to the vibriostatic agent $\mathrm{O} / 129(150 \mu \mathrm{g})$. Positive for glucose oxidation-fermentation, lysine decarboxylase, methyl red and ONPG tests. Negative for arginine dihydrolase, ornithine decarboxylase and Voges-Proskauer tests. Negative for brown diffusible pigment, swarming, and production of gas from D-glucose and hydrogen sulfide from cysteine and thiosulfate. Grows on MacConkey agar and m-Aeromonas-selective agar base Havelaar. Able to grow at $\mathrm{pH} 9.0$ and $0-3 \% \mathrm{NaCl}$, grows weakly at $6 \% \mathrm{NaCl}$ but does not grow at $\mathrm{pH} 4.5$ or $7 \% \mathrm{NaCl}$. Hydrolyses arbutin, DNA, aesculin, gelatin and starch, but not elastin, erythrocytes, urea or xanthine. Produces acid from Larabinose, arbutin, dextrin, D-galactose, glycerol, D-mannitol, salicin, sucrose and D-trehalose but not from lactose, D-mannose, D-melibiose, D-raffinose, L-rhamnose, sorbitol or D-xylose. The following substrates are used as sole carbon and energy sources: acetate, $N$-acetylglucosamine, aesculin, L-arabinose, $p$-arbutin, L-arginine, D-cellobiose, citrate, Dfructose, D-galactose, D-glucose, glycerol, L-histidine, Llactate, maltose, D-mannitol, salicin, starch, sucrose and

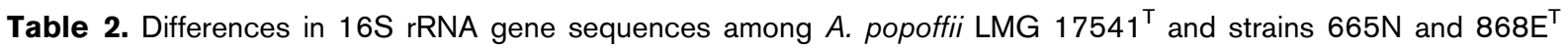

Positions refer to the Escherichia coli sequence numbering system (Brosius et al., 1978).

\begin{tabular}{|c|c|c|c|c|c|c|c|}
\hline Strain & GenBank accession no. & \multicolumn{6}{|c|}{ Position } \\
\hline $665 \mathrm{~N}$ & DQ504430 & A & $\mathrm{C}$ & $\mathrm{T}$ & $\mathrm{T}$ & $\mathrm{C}$ & G \\
\hline $868 \mathrm{E}^{\mathrm{T}}$ & DQ504429 & A & $\mathrm{C}$ & $\mathrm{T}$ & $\mathrm{T}$ & $\mathrm{T}$ & A \\
\hline
\end{tabular}




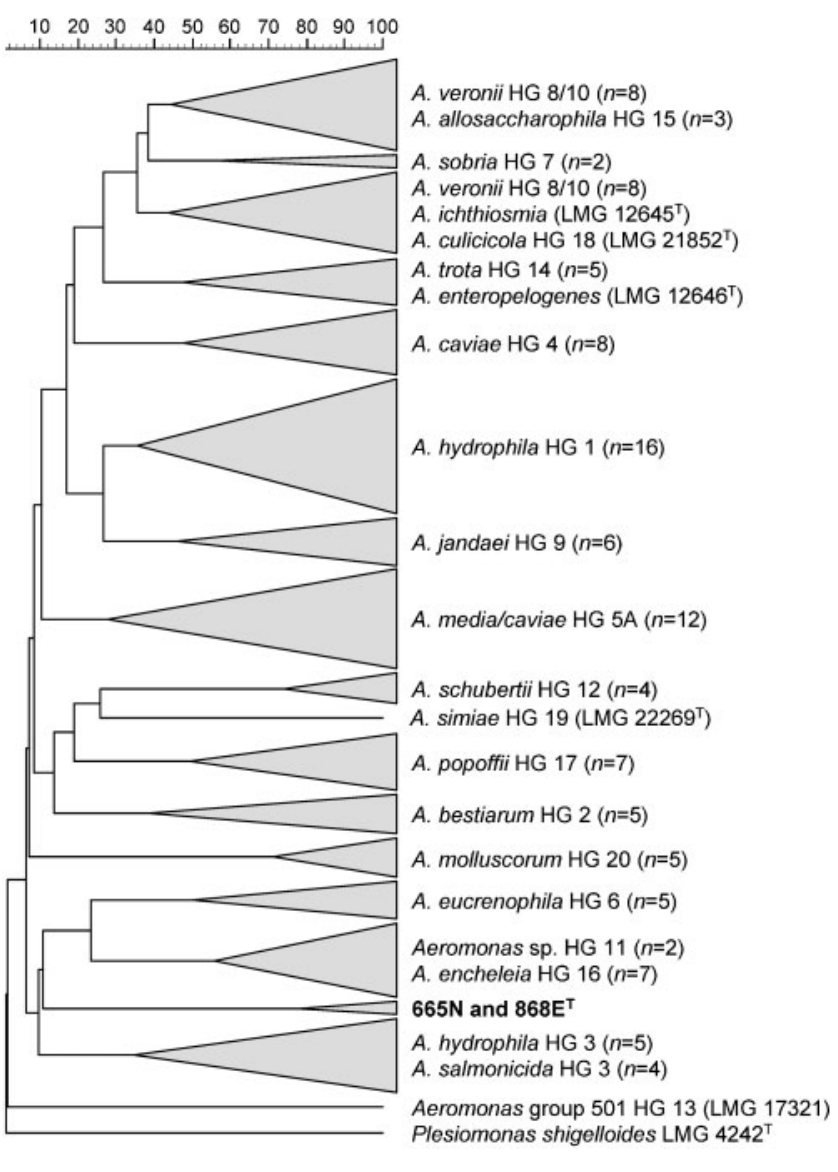

Fig. 2. Simplified dendrogram showing cluster analysis of the FAFLP fingerprints of strains $665 \mathrm{~N}$ and $868 \mathrm{E}^{\top}$ and reference strains of the Aeromonas DNA hybridization groups. The Aeromonas reference strains from the AEROLIB database are listed in Huys \& Swings (1999), Huys et al. (2003) and Miñana-Galbis et al. (2004), except for A. simiae LMG $22269^{\top}$ and strains $665 \mathrm{~N}$ and $868 \mathrm{E}^{\top}$, which were added to the database in the framework of the current study. The dendrogram was constructed with the UPGMA clustering method by using the Pearson product-moment correlation coefficient (expressed as a percentage).

D-trehalose. Does not use adonitol, dulcitol, inositol, lactose, D-mannose, D-melezitose, D-melibiose, D-raffinose, L-rhamnose, sorbitol, L-sorbose or D-xylose. Resistant to amoxycillin/clavulanic acid $(30 \mu \mathrm{g})$, ampicillin $(10 \mu \mathrm{g})$, erythromycin $(15 \mu \mathrm{g})$ and penicillin $\mathrm{G}(10 \mu \mathrm{g})$, shows intermediate sensitivity to cefuroxime $(30 \mu \mathrm{g})$ and streptomycin $(10 \mu \mathrm{g})$ and is sensitive to amikacin $(30 \mu \mathrm{g})$, ceftriaxone $(30 \mu \mathrm{g})$, ciprofloxacin $(5 \mu \mathrm{g})$, colistin $(50 \mu \mathrm{g})$, gentamicin $(10 \mu \mathrm{g})$, imipenem $(10 \mu \mathrm{g})$, polymyxin $\mathrm{B}$ $(300 \mathrm{U})$, tetracycline $(30 \mu \mathrm{g})$, tobramycin $(10 \mu \mathrm{g})$ and trimethoprim/sulfamethoxazole $(1.25 / 23.75 \mu \mathrm{g})$. Strain $665 \mathrm{~N}$ is resistant to cephalothin $(30 \mu \mathrm{g})$, cefoxitin $(30 \mu \mathrm{g})$ and ticarcillin $(75 \mu \mathrm{g})$, whereas strain $868 \mathrm{E}^{\mathrm{T}}$ is not. The DNA $\mathrm{G}+\mathrm{C}$ content is $62.3 \mathrm{~mol} \%$ for strain $665 \mathrm{~N}$ and $62.6 \mathrm{~mol} \%$ for strain $868 \mathrm{E}^{\mathrm{T}}$.
The type strain, $868 \mathrm{E}^{\mathrm{T}}$ ( = CECT $7113^{\mathrm{T}}=\mathrm{LMG} 23376^{\mathrm{T}}$ ), was isolated from cockles (Cardium sp.) obtained from a retail market in Barcelona (Spain). Strain 665N (=CECT $7112=\mathrm{LMG} 23377)$ is a second strain of the species.

\section{Acknowledgements}

This work was supported by project CGL2004-03385/BOS from the Ministerio de Educación y Ciencia, Spain. We thank the Serveis Cientificotècnics of the Universitat de Barcelona (Unitats de Genòmica i de Microscòpia Electrònica) for assistance. We acknowledge the $\mathrm{BCCM}^{\mathrm{TM}} / \mathrm{LMG}$ Identification Service of Gent University for performing the DNA $\mathrm{G}+\mathrm{C}$ content determination and FAFLP and DNA-DNA hybridization analyses. We thank Professor Dr H. G. Trüper for helping with the nomenclature of the novel species. This paper is dedicated to the memory of Spanish microbiologist Dr Jesús Guinea Sánchez.

\section{References}

Abbott, S. L., Cheung, W. K. W. \& Janda, J. M. (2003). The genus Aeromonas: biochemical characteristics, atypical reactions, and phenotypic identification schemes. J Clin Microbiol 41, 2348-2357.

Altwegg, M., Steigerwalt, A. G., Altwegg-Bissig, R., LüthyHottenstein, J. \& Brenner, D. J. (1990). Biochemical identification of Aeromonas genospecies isolated from humans. J Clin Microbiol 28, 258-264.

Brosius, J., Palmer, M. L., Kennedy, P. J. \& Noller, H. F. (1978). Complete nucleotide sequence of a $16 \mathrm{~S}$ ribosomal RNA gene from Escherichia coli. Proc Natl Acad Sci U S A 75, 4801-4805.

Carson, J., Wagner, T., Wilson, T. \& Donachie, L. (2001). Miniaturized tests for computer-assisted identification of motile Aeromonas species with an improved probability matrix. $J$ Appl Microbiol 90, 190-200.

Esteve, C., Valera, L., Gutiérrez, C. \& Ventosa, A. (2003). Taxonomic study of sucrose-positive Aeromonas jandaei-like isolates from faeces, water and eels: emendation of A. jandaei Carnahan et al. 1992. Int J Syst Evol Microbiol 53, 1411-1419.

Ezaki, T., Hashimoto, Y. \& Yabuuchi, E. (1989). Fluorometric deoxyribonucleic acid-deoxyribonucleic acid hybridization in microdilution wells as an alternative to membrane filter hybridization in which radioisotopes are used to determine genetic relatedness among bacterial strains. Int J Syst Bacteriol 39, 224-229.

Gevers, D., Huys, G. \& Swings, J. (2001). Applicability of rep-PCR fingerprinting for identification of Lactobacillus species. FEMS Microbiol Lett 205, 31-36.

Harf-Monteil, C., Le Flèche, A., Riegel, P., Prévost, G., Bermond, D., Grimont, P. A. D. \& Monteil, H. (2004). Aeromonas simiae sp. nov., isolated from monkey faeces. Int J Syst Evol Microbiol 54, 481-485.

Huys, G. \& Swings, J. (1999). Evaluation of a fluorescent amplified fragment length polymorphism (FAFLP) methodology for the genotypic discrimination of Aeromonas taxa. FEMS Microbiol Lett 177, 83-92.

Huys, G., Kämpfer, P., Altwegg, M., Coopman, R., Janssen, P., Gillis, M. \& Kersters, K. (1997). Inclusion of Aeromonas DNA hybridization group 11 in Aeromonas encheleia and extended descriptions of the species Aeromonas eucrenophila and A. encheleia. Int J Syst Bacteriol 47, $1157-1164$.

Huys, G., Kämpfer, P., Albert, M. J., Kühn, I., Denys, R. \& Swings, J. (2002). Aeromonas hydrophila subsp. dhakensis subsp. nov., isolated from children with diarrhoea in Bangladesh, and extended description of Aeromonas hydrophila subsp. hydrophila (Chester 
1901) Stanier 1943 (Approved Lists 1980). Int J Syst Evol Microbiol 52, 705-712.

Huys, G., Pearson, M., Kämpfer, P., Denys, R., Cnockaert, M., Inglis, V. \& Swings, J. (2003). Aeromonas hydrophila subsp. ranae subsp. nov., isolated from septicaemic farmed frogs in Thailand. Int J Syst Evol Microbiol 53, 885-891.

Huys, G., Cnockaert, M. \& Swings, J. (2005). Aeromonas culicicola Pidiyar et al. 2002 is a later subjective synonym of Aeromonas veronii Hickman-Brenner et al. 1987. Syst Appl Microbiol 28, 604-609.

Kämpfer, P., Christmann, C., Swings, J. \& Huys, G. (1999). In vitro susceptibilities of Aeromonas genomic species to 69 antimicrobial agents. Syst Appl Microbiol 22, 662-669.

Kumar, S., Tamura, K., Jakobsen, I. B. \& Nei, M. (2001). MEGA2: molecular evolutionary genetic analysis software. Bioinformatics 17, 1244-1245.

Martin-Carnahan, A. \& Joseph, S. W. (2005). Genus I. Aeromonas Stanier 1943, 213 ${ }^{\mathrm{AL}}$. In Bergey's Manual of Systematic Bacteriology, vol. 2, part B, p. 557-578. Edited by G. M. Garrity, D. J. Brenner, N. R. Krieg \& J. T. Staley. New York: Springer.

Martínez-Murcia, A. J., Antón, A. I. \& Rodríguez-Valera, F. (1999). Patterns of sequence variation in two regions of the $16 \mathrm{~S}$ rRNA multigene family of Escherichia coli. Int J Syst Bacteriol 49, 601-610.

Mesbah, M., Premachandran, U. \& Whitman, W. B. (1989). Precise measurement of the $\mathrm{G}+\mathrm{C}$ content of deoxyribonucleic acid by highperformance liquid chromatography. Int J Syst Bacteriol 39, 159-167.

Miñana-Galbis, D., Farfán, M., Lorén, J. G. \& Fusté, M. C. (2002). Biochemical identification and numerical taxonomy of Aeromonas spp. isolated from environmental and clinical samples in Spain. J Appl Microbiol 93, 420-430.

Miñana-Galbis, D., Farfán, M., Fusté, M. C. \& Lorén, J. G. (2004). Aeromonas molluscorum sp. nov., isolated from bivalve molluscs. Int J Syst Evol Microbiol 54, 2073-2078.

Morandi, A., Zhaxybayeva, O., Gogarten, J. P. \& Graf, J. (2005). Evolutionary and diagnostic implications of intragenomic heterogeneity in the $16 \mathrm{~S}$ rRNA gene in Aeromonas strains. J Bacteriol 187, 6561-6564.

Pavan, M. E., Abbott, S. L., Zorzópulos, J. \& Janda, J. M. (2000). Aeromonas salmonicida subsp. pectinolytica subsp. nov., a new pectinase-positive subspecies isolated from a heavily polluted river. Int J Syst Evol Microbiol 50, 1119-1124.

Pidiyar, V., Kaznowski, A., Narayan, N. B., Patole, M. \& Shouche, Y. S. (2002). Aeromonas culicicola sp. nov., from the midgut of Culex quinquefasciatus. Int J Syst Evol Microbiol 52, 1723-1728.

Smibert, R. M. \& Krieg, N. R. (1994). Phenotypic characterization. In Methods for General and Molecular Bacteriology, pp. 607-655. Edited by P. Gerhardt, R. G. E. Murray, W. A. Wood \& N. R. Krieg. Washington, DC: American Society for Microbiology.

Soler, L., Yáñez, M. A., Chacon, M. R., Aguilera-Arreola, M. G., Catalán, V., Figueras, M. J. \& Martínez-Murcia, A. J. (2004). Phylogenetic analysis of the genus Aeromonas based on two housekeeping genes. Int J Syst Evol Microbiol 54, 1511-1519.

Stackebrandt, E., Frederiksen, W., Garrity, G. M., Grimont, P. A. D., Kämpfer, P., Maiden, M. C. J., Nesme, X., Rosselló-Mora, R., Swings, J. \& other authors (2002). Report of the ad hoc committee for the re-evaluation of the species definition in bacteriology. Int $J$ Syst Evol Microbiol 52, 1043-1047.

Valera, L. \& Esteve, C. (2002). Phenotypic study by numerical taxonomy of strains belonging to the genus Aeromonas. J Appl Microbiol 93, 77-95.

Wayne, L. G., Brenner, D. J., Colwell, R. R., Grimont, P. A. D., Kandler, O., Krichevsky, M. I., Moore, L. H., Moore, W. E. C., Murray, R. G. E. \& other authors (1987). International Committee on Systematic Bacteriology. Report of the ad hoc committee on reconciliation of approaches to bacterial systematics. Int $J$ Syst Bacteriol 37, 463-464.

Wilson, K. (1987). Preparation of genomic DNA from bacteria. In Current Protocols in Molecular Biology, pp. 2.4.1-2.4.5. Edited by F. M. Ausubel, R. Brent, R. E. Kingston, D. D. Moore, J. G. Seidman, J. A. Smith \& K. Struhl. New York: Greene Publishing and WileyInterscience. 